\title{
Van tematiese na alfabetiese na tematiese ordening in woordeboeke - wisselwerking tussen teorie en praktyk
}

\author{
Rufus H. Gouws \\ Departement Afrikaans en Nederlands, Universiteit Stellenbosch, Suid-Afrika \\ E-pos: rhg@sun.ac.za
}

\section{Opsomming}

Vroeë woordeboeke is gekenmerk deur 'n tematiese ordening. Dit is eers later in die leksikografiese praktyk dat die alfabetiese ordening 'n dominante rol begin speel het, alhoewel die tematiese benadering steeds in bepaalde woordeboeksoorte gehandhaaf is. Die hedendaagse leksikografiese praktyk toon 'n nuwe benadering tot makrostrukturele ordening met 'n hibridiese aanbod van opeenvolgende makrostrukture waarin sowel die alfabetiese as die tematiese beginsels 'n ordeningsrol speel. Hierdie artikel gee aandag aan die ontwikkeling van die leksikografiese praktyk en die motivering vir 'n tematiese ordening in die vroeë woordeboeke. Voorts word die oorgang na 'n oorwegend alfabetiese ordening beskryf. Ontwikkeling in die teoretiese leksikografie en die wisselwerking tussen teorie en praktyk lei tot verskillende aanpassings in die makrostrukturele aanbod. Naas die streng alfabetiese ordening is daar tans ook die kronkelordening waar ' $n$ horisontale ordening van lemmata tot artikelniste en artikelneste lei. Hierdie ordening kom veral in gedrukte woordeboeke voor. Morfologiese en semantiese redes speel ' $\mathrm{n}$ rol in die aanpassings van die makrostrukturele ordening. Benewens suiwer alfabetiese en suiwer tematiese woordeboeke is daar vandag talle woordeboeke met 'n hibridiese ordening. In die makrostruktuurreeks van 'n enkele woordeboek is sommige tekste alfabeties en ander tematies georden. Hierdie aanpassings word nie lukraak gedoen nie, maar wel ter erkenning van die gebruikersperspektief wat 'n dominante rol in die leksikografiepraktyk speel. Vernuwende makrostrukturele benaderings om spesifieke gebruikersgroepe in spesifieke gebruiks- en gebruikersituasies ten beste te kan help in hulle woordeboekraadpleging word aan die hand van bestaande woordeboeke bespreek. Die belang daarvan dat 'n woordeboek 'n goeie teoretiese basis moet hê, dien as uitgangspunt en die aanpassings in die leksikografiepraktyk word vanuit hierdie teoretiese benadering verklaar.

Trefwoorde: alfabetiese ordening, hibriede makrostrukture, makrostruktuur, makrostruktuurreeks, tematiese ordening 


\title{
From thematic to alphabetic to thematic ordering in dictionaries - interaction between theory and practice
}

\begin{abstract}
Early dictionaries were characterised by a thematic ordering. Alphabetical ordering came to play a dominant role only later in lexicographic practice, although thematic ordering has been maintained in certain dictionaries. Modern-day lexicographic practice reflects a new approach to macrostructural ordering with a hybrid product of successive macrostructures in which both alphabetical and thematic principles have an ordering role to play. This article focuses on the development of the lexicographic practice and the reasoning behind a thematic ordering in early dictionaries. Subsequently the transition to a predominantly alphabetical ordering is described. Developments in theoretical lexicography and the interaction between theory and practice resulted in various adaptations in the macrostructural product. Apart from strict alphabetical ordering, modern-day sinuous ordering involves horizontal ordering of lemmata, leading to article niching and article nesting. This type of ordering mostly prevails in printed dictionaries. Morphological and semantic reasons have a role to play in adaptations in the macrostructural ordering. In addition to purely alphabetical and purely thematic dictionaries, there are many dictionaries these days that offer a hybrid ordering. In the macrostructural series of a single dictionary, certain texts are ordered alphabetically, while others are ordered thematically. These changes are not done in a haphazard way but according to the user perspective, which plays a dominant role the lexicographic practice. Innovative macrostructural approaches to optimise dictionary consultation for specific target user groups in specific user situations and situations of use are discussed in the context of existing dictionaries. The importance of a dictionary having a sound theoretical foundation serves as a point of departure.
\end{abstract}

Keywords: alphabetical ordering, hybrid macrostructures, macrostructural series, macrostructure, thematic ordering

\section{Inleidend}

Leon de Stadler se belangrike bydrae tot die Afrikaanse leksikografie, die Groot tesourus van Afrikaans (De Stadler en De Stadler 1994), is 'n woordeboek waarvan die makrostrukturele aanbieding nie 'n primêre alfabetiese ordening handhaaf nie. Met waardering vir en erkenning aan die reusebydrae wat Leon en Amanda de Stadler met die Groot tesourus van Afrikaans gelewer het, maar ook met waardering vir Leon de Stadler se jarelange betrokkenheid by die Afrikaanse taalkunde en sy gewaardeerde verbintenis met die Universiteit Stellenbosch se Departement Afrikaans en Nederlands, word verskillende aspekte van leksikografiese makrostrukture in hierdie artikel bespreek.

Die gemiddelde hedendaagse woordeboekgebruiker beskou 'n woordeboek as 'n naslaanbron met 'n lys alfabeties geordende woorde waarop kommentaar gelewer word. So 'n siening is nie noodwendig verkeerd nie, maar dit is onpresies en geld nie ten opsigte van alle woordeboeksoorte nie.

Dit is so dat die makrostruktuur van die meerderheid woordeboeke wat vandag deur die tipiese woordeboekgebruiker geraadpleeg word, hetsy tweetalig hetsy eentalig, wel alfabeties georden is. In die tipologiese klassifikasie van woordeboeke is die een opvallende uitsondering op 
hierdie ordeningswyse die tesourus - 'n woordeboeksoort wat met sy onomasiologiese benadering ' $n$ ordening volgens begrippe eerder as ' $n$ alfabetiese ordening van woorde daarstel. Dit is ' $n$ woordeboeksoort wat vandag steeds voorkom alhoewel in 'n veel mindere mate as vroeër.

$\mathrm{Al}$ is die alfabetiese ordening tans die verstekbenadering moet dit nie noodwendig as die enigste geldende makrostrukturele ordeningsmetode gesien word nie - nie histories nie en ook nie met betrekking tot talle hedendaagse woordeboeke nie. Naas die oorwig in vroeë woordeboeke ten gunste van 'n nie-alfabetiese ordening is daar tans in baie alfabetiese woordeboeke ook bepaalde toepassings van 'n nie-alfabetiese ordening. Hierdie ordening is nie toevallig nie, maar eerder die toepassing van bepaalde voorstelle vanuit die teoretiese leksikografie. Sekere aspekte hiervan word in hierdie artikel bespreek.

\section{Historiese oorsig}

Die ontwikkeling van die leksikografiese praktyk het verskillende ingrypende veranderinge beleef, onder meer die oorskakeling van kleitablette na perkamentrol, van perkamentrol na papier, van die gedrukte medium na die elektroniese medium en vanaf woordeboeke op CD ROM na aanlyn woordeboeke. Een oorgang waarvan die impak nooit geringgeskat mag word nie, is die oorgang vanaf die tematiese na die alfabetiese ordening in woordeboeke. Dit was naamlik nie net 'n oorgang met betrekking tot ' $n$ ordeningsmetode nie, maar ook 'n oorgang in die manier waarop woordeboeke as houers van kennis gesien, beplan en saamgestel is.

Na die vroeë leksikografiese werk, onder meer woordelyste op kleitablette in die destydse Babilonië en op papirus in Egipte (vergelyk Al-Kasimi 1977:1), was daar verdere ontwikkeling, byvoorbeeld in die Arabiessprekende wêreld om die Koran toeganklik te maak, in die Engelse leksikografie om op opvoedkundige vlak te help, asook binne die Westerse Christendom. Dit het uiteindelik gelei tot verskillende vernuwende naslaanbronne. In hierdie bronne, onder meer die werk van die skolastici, is daar gepoog om die omne scibile, dit is alles wat wetenswaardig is, vas te vang. Die elfde eeu word gekenmerk deur die verskyning van vocabularia wat moes help met woordeskatverwerwing. Hierdie vroeë woordeboeke was nie alfabeties georden nie, maar tematies (vergelyk McArthur 1986:75). Leksikograwe het naamlik gepoog om met behulp van die temas wat in hulle woordeboeke aan die orde gestel is, iets van 'n bepaalde wêreldsiening weer te gee.

As houer van kennis moes ' $n$ woordeboek 'n afspieëling wees van die bekendste houer van kennis, naamlik die menslike verstand. Daar is ook geargumenteer dat die menslike verstand nie alfabeties georden is nie, maar dat 'n mens eerder tematies dink. Wanneer jy aan kos dink, dink jy nie aan korvet en Kosak, die woord 'kos' se alfabetiese bure, nie, maar eerder aan verskillende soorte kos. Gevolglik is daar probeer om in 'n woordeboek dit bymekaar te bring wat tematies bymekaar pas - en dit het gelei tot die tematiese ordening.

In woordeboeke met ' $n$ tematiese ordening is 'n verskeidenheid temas uit die alledaagse lewe gekies en elk in 'n afsonderlike hoofstuk van die betrokke woordeboek behandel (McArthur 1986:75; Gouws 1989:52; 2014:374). Dit was meer as net 'n ordening; eerder ook 'n weerspieëling van 'n bepaalde wêreldbeeld en lewensiening van die leksikograwe. Die woordeboeke het iets van die werklikheid van die werklike lewe van die gebruiker weerspieël. Hierdie benadering is nie volledig onverwant aan dié van Philip Gove, hoofredakteur van die aanvanklik veel gekritiseerde en later veel gewaardeerde Webster's third new dictionary of the 
English language (1961), nie. Met hierdie woordeboek het Gove hom naamlik die gramskap van talle taalgebruikers en taalkundiges op die hals gehaal omdat hy afgewyk het van die preskriptiewe benadering wat die destydse leksikografiese praktyk gekenmerk het ten gunste van 'n deskriptiewe benadering. Gove het beweer dat 'n woordeboek taal moet opteken en nie die styl moet voorskryf nie en dat woordeboeke die werklike taalgebruik moet weerspieël daardie taal wat gebruik word in die lewens- en werklikheidservaring van sy sprekers; die soort lewenswerklikheid wat in die vroeëre tematiese woordeboeke se hoofstukke vasgevang is.

Om praktiese redes was daar ' $\mathrm{n}$ stadige oorgang na die alfabetiese ordening. In die opstel van die bekende Glossa collectae (versamelings moeilike woorde) tydens die Middeleeue het studente geannoteerde lyste van moeilike woorde gemaak en deurlopend nuwe woorde by die bestaande lyste bygevoeg - wat breedweg maar nie volledig alfabeties georden was nie. Aanpassings in die tegnologie, veral die koms van die drukpers, het die grootste impetus verskaf vir die daadwerklike oorgang van die meerderheid woordeboeke na 'n alfabetiese ordening. Hierdie oorgang was meer as net ' $n$ aanpassing in die ordeningsmetode wat in woordeboeke gevolg is. Dit het ' $n$ ander benadering tot die verpakking van data in woordeboeke geïmpliseer en daardeur ook 'n andersoortige weerspieëling van die leksikon. Die woordeboek het nie meer die kontinuum van die lewe (McArthur 1986:75) weerspieël nie. Bolinger (1985:69) voer aan:

Lexicography is an unnatural occupation. It consists in tearing words from their mother context and setting them in rows carrots and onions and beetroot and salsify next to one another with roots shorn like those of celery to make them fit side by side, in an order determined not by nature but by some obscure Phoenician sailors who traded with Greeks in the long ago.

En dan:

Half of the lexicographer's labor is spent repairing this damage to an infinitude of natural connections that every word in any language contracts with every other word, in a complex neural web knit densely at the center but ever more diffusely as it spreads outward.

Die aanduiding van 'n semantiese verband tussen woorde is prysgegee ten gunste van 'n ordening wat geen semantiese verhouding weergee nie. Die alfabetiese ordening het ook 'n andersoortige kennis aan die kant van die teikengebruikers veronderstel. Wiegand en Beer (2013:114) beweer tereg dat enige alfabet bifunksioneel is. Dit het sowel 'n verskriftelikingsas 'n ordeningsfunksie. Gebruikers moes eers met die verskriftelikingsfunksie vertroud raak alvorens hulle die waarde van die ordeningsfunksie wat die alfabet in woordeboeke meebring ten volle kon benut.

Die oorgang na die alfabetiese ordening in woordeboeke het nie tot eenvormige ordeningsmetodes gelei wat uitsluitlik op die alfabet berus het nie. Verskillende tipes makrostrukturele ordening met 'n mindere of meerdere benutting van die alfabet sou in daaropvolgende eeue in die leksikografiese praktyk ingespan word. Die opkoms van die metaleksikografie en die wisselwerking tussen teorie en praktyk sou hier 'n bepaalde invloed uitoefen. 


\section{Verskillende tipes alfabetiese ordening}

\section{1. 'n Toegangsalfabet}

In die teoretiese en praktiese leksikografie word daar vir verskillende tipes makrostrukture voorsiening gemaak (Wiegand 1989; Gouws en Prinsloo 2005; Wiegand en Gouws 2013). Al is die alfabet die basis van die algemeenste ordeningsmetode wat tans in woordeboeke gevolg word, is dit nie die enigste metode nie. Tematiese ordening kom steeds voor en daar is vernuwende werkswyses in hierdie verband. Daarnaas is daar verskillende variante van hibridiese ordeningsmetodes wat sowel 'n alfabetiese as 'n tematiese werkswyse in 'n enkele woordeboek vertoon. Verskeie aspekte van makrostrukturele verskeidenheid in die onlangse leksikografie word vervolgens bespreek - ook ter aanduiding van onderlinge verskille in makrostrukture wat breedweg as behorende tot 'n alfabetiese ordening geklassifiseer word.

Waar woordeboeke soos die Glossa collectae slegs 'n gedeeltelike alfabetiese ordening vertoon het, met die ordening dikwels slegs volgens die eerste letter van 'n woord, word 'n strak aanvangsalfabetiese ordening in talle moderne woordeboeke gevolg. Dit beteken dat die makrostrukturele plasing van 'n woord volgens die alfabetiese waarde van al die letters waaruit die woord bestaan, sal geskied en wel in die volgorde van voor na agter - dus nie 'n retrograde volgorde nie. Hiervolgens sal geweld voor gewelf georden word omdat daar 'n verskil ten opsigte van die laaste letter is met $d$ wat $f$ alfabeties voorafgaan. In 'n alfabetiese ordening kan daar in bepaalde woordeboeke wel sekere ad hoc-bepalings oor die plasing van lemmata gevolg word, onder meer met betrekking tot die lemmatisering van alfa-numeriese leksikale items vergelyk in hierdie verband lemmakandidate soos 3D-drukker, 4x4-roete en .303-geweer of dié lemmas wat 'n simbool as stam bevat, byvoorbeeld $\alpha$-partikel, \$-note of \#-veldtogte.

In die beplanning van elke woordeboek moet die leksikograaf voorsiening maak vir 'n toegangsalfabet waarvolgens leksikale items wat nie suiwer alfabeties saamgestel is nie, gelemmatiseer kan word. Dit gaan hier om 'n verandering van 'n element-homogene alfabetiese makrostruktuur na 'n element-heterogene alfabetiese makrostruktuur, soos bespreek in Wiegand en Gouws (2013:103). In die besluit oor die plasing van sulke lemmas speel die dataverspreidingstruktuur van die betrokke woordeboek 'n belangrike rol. Die leksikograaf moet naamlik reeds in die beplanning van die woordeboek besluit waar spesifieke datainskrywings geplaas word. Indien sulke leksikale items wel in die makrostruktuur van die sentrale teks opgeneem word, is die vraag in watter artikeltrajek hulle tuishoort. 'n Tipiese werkswyse is om die makrostrukturele plasing te doen volgens die alfabetiese waarde van die woordekwivalent van die syfer of simbool wat as eerste komponent van die leksikale item optree. Daarvolgens sal .303-geweer, 3D-drukker en \$-note onderskeidelik in die artikeltrajekte $P$ en $D$ opgeneem word asof die items punt 303-geweer, drie-D-drukker en dollarnote is. Dit bring 'n verandering in die aard van die strak alfabetiese makrostruktuur mee - waar die strak alfabetiese ordening volgens Wiegand (1989:383) daarna verwys dat alle gidselementdraers, dit is die lemmatekens, volgens die woordeboek se vasgestelde toegangsalfabet georden is.

Dit is ook nie net die alfabetiese, numeriese of simboolwaarde van 'n lemma se samestellende elemente wat die plasing volgens die toegangsalfabet bepaal nie. 'n Woordeboekplan moet naamlik ook daarvoor voorsiening maak dat leksikale items wat diakritiese tekens bevat, asook dié waarin 'n koppelteken of 'n spasie optree op 'n konsekwente manier gelemmatiseer word. Naas 'n strak alfabetiese ordening wat slegs aanvangsalfabeties bepaal word, is daar ook ander faktore wat die plasing van lemmas beïnvloed. Hoe moet die ordening van byvoorbeeld waas 
en wa-as of eerste klas en eersteklas gedoen word? Volgens watter kriteria vind die onderlinge ordening van lemmata soos leer, leër en lêer plaas? Die invoer van 'n toegangsalfabet as ordeningsmiddel lei tot besluite in hierdie verband. 'n Tipiese benadering is dat 'n koppelteken voor 'n letter kom; daarom wa-as voor waas, en niks kom altyd voor iets; daarom maak die spasie in eerste klas dat dié lemma voor eersteklas georden word. Dié ordeningsbeginsel bepaal ook die volgorde leer, leër, lêer. 'n Ongemerkte letter word voor 'n gemerkte letter georden. Die konsekwente toepassing van so 'n toegangsalfabet, handhaaf die betrokke woordeboek se strak alfabetiese ordening.

Die dataverspreidingstruktuur van 'n woordeboek is op die woordeboek as geheel gerig en nie net op die sentrale teks nie. As 'n draer van tekssoorte beskik 'n woordeboek nie net oor die sentrale teks as data-akkommodasieplek nie, maar buitetekste kan ook daarvoor benut word veral as die woordeboek 'n raamstruktuur vertoon met voor- en agtertekste om die data-aanbod en -bewerking in die sentrale teks aan te vul (Kammerer en Wiegand 1998; Gouws 2004). Alhoewel die sentrale teks ' $\mathrm{n}$ alfabetiese ordening het, hoef hierdie ordening nie noodwendig in al die buitetekste gehandhaaf te word nie. Die Macmillan English dictionary (MED) (Rundell 2002) se sentrale teks vertoon 'n alfabetiese ordening. Dié woordeboek het 'n buiteteks "Numbers that are entries" wat slegs daardie lemmata bevat wat nie binne die alfabetiese ordening in die sentrale teks tuishoort nie. Dit sluit lemmata in soos 0800 number; 1922 Committee, the; 20/20 vision; 2.2; 4WD; $\$ 64000$ question, the. Die opname van so 'n buiteteks impliseer dat die betrokke woordeboek 'n makrostruktuurreeks bevat (vergelyk Wiegand en Gouws 2013:83). Die ordening in hierdie buiteteks geskied van laag na hoog volgens die numeriese waarde van die eerste numeriese element in die lemma. Die lemmas in hierdie makrostruktuur kan onderskei word van die lemmas in die sentrale teks van die woordeboek aangesien dit hier om 'n bepaalde onderafdeling van die leksikon gaan. Sekere lemmakandidate is dus uitgefaseer vanaf die sentrale teks na 'n buiteteks - wat met betrekking tot die werklike doel van die betrokke woordeboeke steeds as 'n geïntegreerde buiteteks beskou moet word (vergelyk Bergenholtz, Tarp en Wiegand 1999 vir 'n bespreking van geïntegreerde buitetekste). Die subklassifikasie waartoe hierdie buiteteks behoort, is weliswaar nie dié van 'n semantiestematiese makrostruktuur nie, maar eerder dié van 'n numeries-tematiese makrostruktuur met 'n ordening wat volgens 'n stygende numeriese waarde bepaal word.

Die plasing van element-heterogene lemmas óf in die makrostruktuur van die sentrale teks óf in die makrostruktuur van ' $n$ buiteteks word nie lukraak gedoen nie. Die teoretiese benadering tot 'n toegangsalfabet en tot 'n raamstruktuur met die moontlikheid van buitetekste om aan 'n verskeidenheid inskrywings 'n leksikografiese tuiste te bied, is van bepalende belang. Die teorie bepaal hoe 'n verandering in die aanbieding en ordening in die praktyk deurgevoer kan word.

\section{2. 'n Streng alfabetiese versus 'n kronkelordening}

Waar 'n alfabetiese ordening in die makrostruktuur gehandhaaf word, is dit nie noodwendig altyd 'n streng alfabetiese ordening nie. Daar is ruimte vir sekere afwykings. Volgens Wiegand en Beer (2013:120) word 'n makrostruktuur met 'n streng alfabetiese ordening daardeur gekenmerk dat die volledige lemmatrajek van 'n aanvangsalfabetiese hooftoegangstruktuur uit niegegroepeerde lemmas bestaan wat nie sublemmas is nie en telkens aan die begin van 'n nuwe reël geplaas is sodat die hooftoegangstruktuur 'n deurlopende vertikale lemmatrajek is. Makrostrukturele afwykings met betrekking tot die rigting van die lemmatrajek kom dikwels voor. Die belangrikste onderskeid wat hier gemaak word, is dié tussen 'n vertikale en 'n 
horisontale makrostrukturele ordening, dit is tussen 'n streng alfabetiese makrostruktuur en 'n makrostruktuur wat 'n kronkelordening vertoon.

In die leksikografiese praktyk speel verskillende kragte 'n beduidende rol. Plek is een van dié kragte wat veral in gedrukte woordeboeke van beslissende belang is. 'n Tipiese woordeboekartikel vertoon sterk invloed van teksverdigting. Die tipiese mikrostrukturele bewerking in 'n woordeboekartikel wyk af van die normale sintaksis. Wiegand (2009:248) voer tereg aan dat daar in woordeboekartikels op 'n onnatuurlike manier oor natuurlike taal gepraat word. Om 'n praktiese rede soos plekbesparing is daar andersoortige makrostrukturele ordeningstipes ingevoer. Kronkelordening is primêr maar nie net ter bereiking van plekbesparing nie. Daar is soms ook sprake daarvan dat die ordening 'n bepaalde soort semantiese samehang, 'n onderskeidende kenmerk van tematies geordende woordeboeke, bewerkstellig. Woordeboekartikels waarvan die lemmas 'n horisontale ordening vertoon, word in twee hoofgroepe verdeel, te wete artikelniste en artikelneste (Wiegand 1989:386-391). Artikelniste en -neste is die gevolg van onderskeidelik nis- en neslemmatisering.

Nislemmatisering word gekenmerk deur 'n horisontale ordening van lemmas, maar die ordeningsafwyking lei nie tot 'n verbreking van die strak alfabetiese ordening nie; net 'n verbreking van die streng alfabetiese ordening. Dit is duidelik uit die volgende voorbeeld uit die Pharos Afrikaans-Engels/English-Afrikaans woordeboek/dictionary (Du Plessis 2005):

ven.ster [=sters] 1 window; 2 glass: blinde $\sim$ mock/blind/dummy window; ronde oculus, bull's-eye (window); jou eie s stukkend gooi cut off one's nose to spite one's face; iets voor die $\sim$ hang/ens. hang/etc. s.t. in front of the window; voor die $\sim$ verskyn appear at the window.

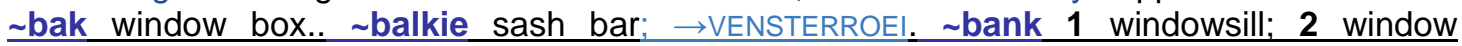
seat/ledge.. blinding (window) blind.. glas 1 window glass; 2 sheet glass, glazing; 3 plate glass.. gordyn window curtain.. haak 1 casement hook; 2 window fastener.. hoogte window level.. knip

Die onderstreepte deel (my onderstreping - RHG) bevat 'n artikelnis van die deeltrajek vensterbak - vensterknip. Hierdie nis verteenwoordig 'n afwyking van die vertikale ordening van die makrostruktuur. Teksverdigting lei daartoe dat elke lemma se eerste stam (venster-) deur ' $n$ tilde as plekhouersimbool vervang word. Dit omskep hierdie nislemmas tot sublemmas (vergelyk Wiegand 2002:521 en Gouws 2007), omdat toegang tot hulle alleen moontlik is via die hooflemma venster. Die nislemmas is gegroepeerde lemmas (vergelyk Bergenholtz, Tarp en Wiegand 1999). Al die lemmas van die nis hoort nie net alfabeties bymekaar nie, maar verteenwoordig samestellings met dieselfde element as eerste stam. Vanuit die teoretiese leksikografie kom 'n aanbeveling ter wille van teksverdigting wat plekbesparing moet bewerk, deur 'n afwyking van die streng alfabetiese ordening ten gunste van 'n makrostruktuur wat morfologiese woordfamilies saamplaas.

Nesting lei tot ' $n$ afwyking van sowel die strak as die streng alfabetiese makrostruktuur. In die geval van nesting is daar ook ' $n$ horisontale ordening van lemmas, maar binne die nes is daar 'n afwyking van die alfabetiese volgorde. Vergelyk die volgende voorbeeld uit die Nasionale woordeboek (De Villiers et al. 1987):

broei (ge-) ww. 1. op eiers sit en hulle warm hou om hulle te laat uitkom. 2. voortkom, ontspruit. Daaruit sal onheil -. 3. peins, planne maak. Oor iets -. 4. ontwikkel, in wording wees. Daar is iets aan die - 5. hitte ontwikkel, warm word. Die mis, lug 6. warm word deur gisting. Die hooi . 7. deur spesiale verwarming vroeër laat bloei of ryp word. 8. warm kry. In die son sit en -. 9. kleintjies voortbring. Die jakkalse - in die lente. 'broeiery, broeiing; broei-eend, -eiers, -gans, 
-hen, -hok, -kamer, -kolonie, -paar, -proses, -sak, -tent (by 1); -mis (by 5); -aarde, -bed (by 6); -bak, -glas, -huise (by 7).

Die onderstreepte deel (my onderstreping - RHG) verteenwoordig 'n lemmanes. In hierdie nes is daar 'n gedeeltelike handhawing van die alfabetiese ordening maar dié ordening word verskeie kere deurbreek. Lemmas word soms deur kommas en soms deur kommapunte van mekaar geskei. Die kommas en kommapunte tree nie hier as leestekens op nie maar as 'n bepaalde tipe leksikografiese inskrywing, naamlik as struktuurmerkers, wat 'n bepaalde tipe skeiding tussen opeenvolgende lemmas merk. Kommas dui daarop dat die lemmas wat deur die komma geskei word tot dieselfde subgroepering behoort, terwyl kommapunte op verskillende subgroeperinge dui. Die eerste twee lemmas (broeiery en broeiing) is albei afleidings. Die kommapunt na broeiing dui daarop dat 'n volgende morfologiese groepering, te wete samestellings, volg. Kommapunte tussen die samestellings skei lemmas waarin verskillende polisemiese waardes van die eerste stam geaktiveer word. Dit blyk ook uit die semantiese merkers (by 1), (by 5), ensovoorts. Alle samestellings waar die eerste stam dieselfde polisemiese waarde van die lemma broei het, word in alfabetiese volgorde bymekaargeplaas. Hier gaan dit nie net om 'n makrostrukturele afwyking ter wille van die byeenplasing van morfologiese woordfamilies nie, maar die afwyking word ook om semantiese redes gedoen. In hierdie voorbeeld van nesting is daar om morfo-semantiese redes 'n deurbreking van sowel die strak as die streng alfabetiese makrostruktuur.

Uit die wisselwerking tussen teorie en praktyk kom nuwe ordeningsmetodes na vore wat ordening as ' $n$ proses benut ter verhoging van die data-aanbod en die taalkundige data-oordrag in woordeboeke. Binne die breë alfabetiese ordeningsmetode is daar ruim plek vir gemotiveerde afwykings wat bydra tot die bereiking van 'n bepaalde woordeboek se werklike doel.

\section{Terug na 'n tematiese ordening}

Die Groot tesourus van Afrikaans en ander woordeboeke in hierdie tipologiese kategorie, onder meer Louw en Nida se vernuwende en baanbrekende Greek-English lexicon of the New Testament based on semantic domains (1988) (wat weens beperkte ruimte nie in hierdie artikel bespreek word nie) wys op die waarde wat tematies geordende woordeboeke vandag nog het. In die hedendaagse leksikografie speel die gebruikersperspektief 'n deurslaggewende rol in die beplanning en samestelling van woordeboeke. Die behoeftes van gebruikers bepaal watter woordeboeke saamgestel en hoe dit saamgestel moet word. Alhoewel die grootste aanvraag na semasiologiese woordeboeke is, mag die rol en belang van onomasiologiese woordeboeke nie ontken of geringgeskat word nie. In die beplanning van die ordeningstipe speel die behoeftes en naslaanvaardighede van die teikengebruikers van die betrokke woordeboek 'n bepalende rol.

'n Voorbeeld van 'n onlangse woordeboek waar die gebruikersbehoeftes maar ook die werklike doel van die woordeboek 'n tematiese ordening tot gevolg gehad het, is die Jul'hoan Tsumkwe dialect/Prentewoordeboek vir kinders/Children's picture dictionary (Jones et al. 2014). Hierdie woordeboek se sentrale lys bevat die volgende temas: Diere; Voëls; Insekte, reptiele en goggas; Tuiste en die gesin; Jag; Versamel en Dans (vergelyk figuur 1 - die begin van die tema Diere). 


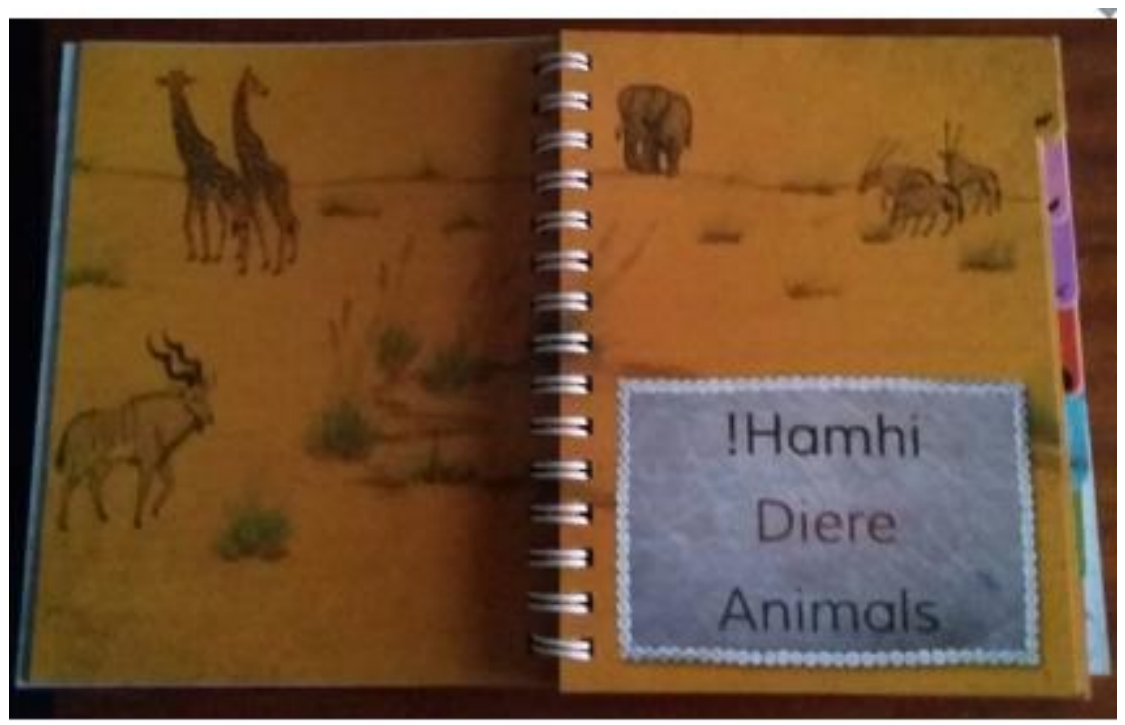

Figuur 1: Die begin van die tema Diere (Jones et al. 2014)

'n Slagspreuk van die opstellers van hierdie woordeboek is "Hou jou mense, jou taal en jou kultuur na aan mekaar." Die temas in hierdie woordeboek verteenwoordig tipiese gebiede uit die kulturele alledaagse lewe van die teikengroep, en die werklike doel van hierdie woordeboek is om die moedertaalsprekers van Jul'hoan, 'n Khoesantaal, bewus te maak van hulle kulturele en taalerfenis. Die keuse van 'n tematiese ordening is gemotiveer deur hierdie werklike doel en die metaleksikografie se aandrang op gebruikersgedrewe woordeboeke. As prentewoordeboek is die hoofinskrywing in elke artikel die prent wat die betrokke saak voorstel. Binne die tematiese veld tree die prente as gidselemente van hulle onderskeie artikels op, soos blyk uit figuur 2:

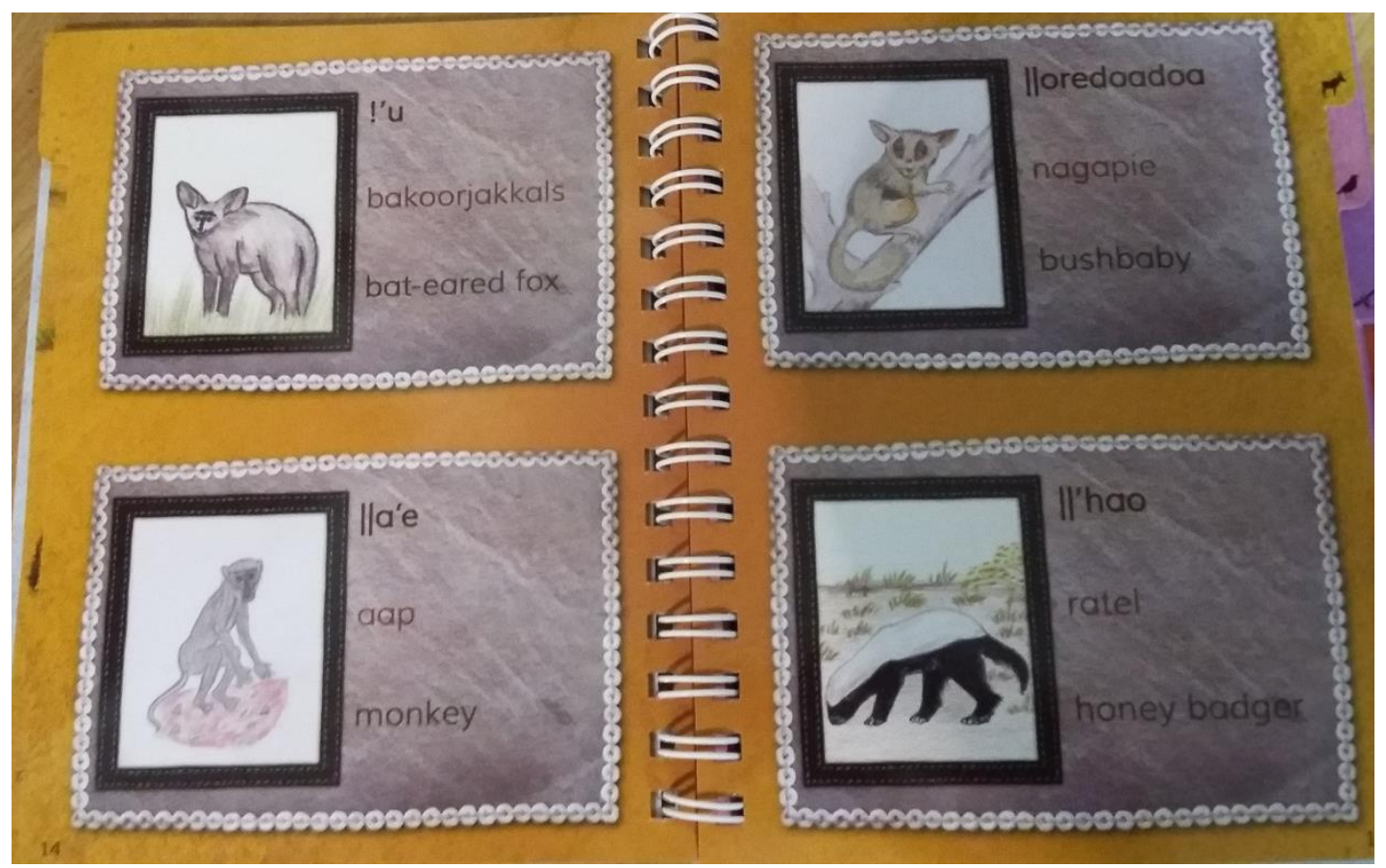

Figuur 2: Prente tree as gidselemente van hul onderskeie artikels op (Jones et al. 2014:14-15) 
Die makrostrukturele ordening geskied nie op grond van die prente nie, maar waarskynlik op grond van die alfabeties-fonetiese waarde van die betrokke Jul'hoan-woorde. Jul'hoan word gekenmerk deur verskillende klikklanke. 'n Hibridiese ortografie word vir die weergawe van die Jul'hoan-woorde in hierdie woordeboek gebruik. Naas die alfabet word fonetiese tekens wat die verskillende klikklanke aandui ook in die skryfwyse aangebied. Die makrostrukturele ordening is soms alfabeties, byvoorbeeld die tema Tuiste en die gesin bevat die volgende alfabetiese deelartikeltrajek: khukhu (hoender), kitiri (ketel), kopi (koppie), kxo (pot) en mama (ouma). In die tema Dans is twee opeenvolgende artikels dié vir $g \mid u$ (nag) en $g ! a$ (reën). Uit hierdie en ander voorbeelde is dit duidelik dat verskillende klikklankmerkers ook 'n invloed op die ordening het. Dit word egter nie verklaar nie en die ordeningsbeginsels is nie oral ewe duidelik nie. In die toeligtingsvoorteks word die volgende tabel (figuur 3) aangegee (sonder 'n verklaring), maar dit word nie konsekwent as toegangsalfabet gebruik nie:

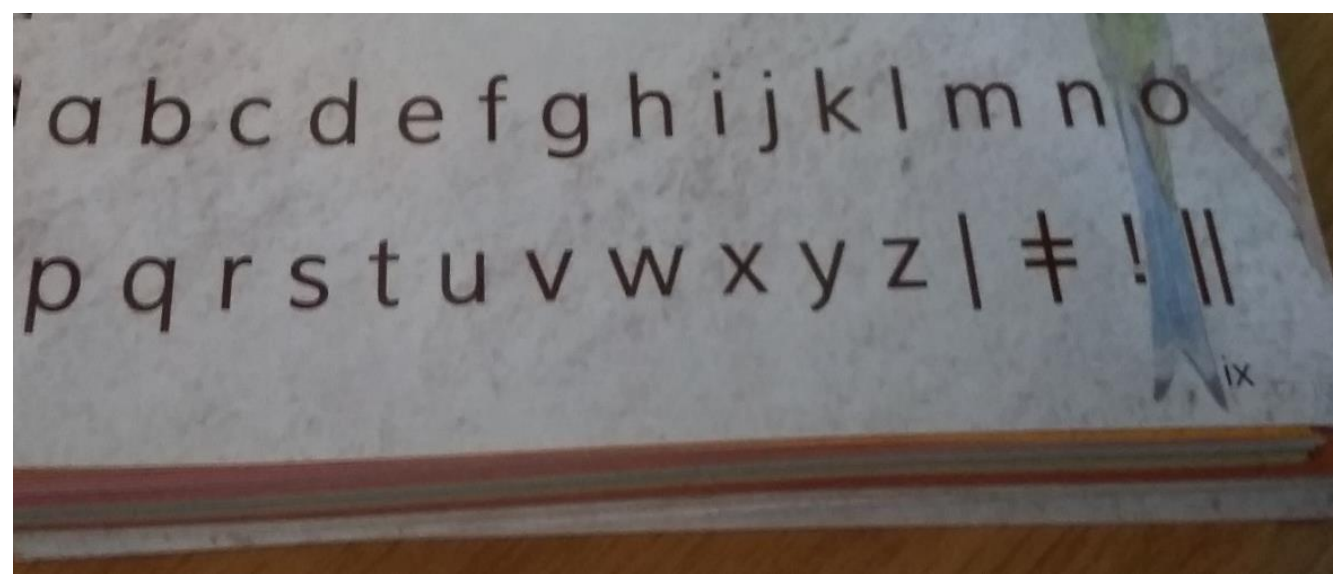

Figuur 3: 'n Hibridiese ortografie word gebruik (Jones et al. 2014:ix)

Al word die tema-interne makrostrukturele ordening in hierdie woordeboek nie genoegsaam verklaar nie, is die eksterne toegangstruktuur goed ontwikkel. Die bladsye van elke tematrajek is in 'n ander kleur. Die eerste bladsy van elk van hierdie trajekte het die naam van die spesifieke tema (vergelyk weer figuur 1), en 'n klein prentjie wat 'n tipiese lid van die betrokke tema voorstel, is op ' $n$ duimindeks aangebring en word regs bo op elke bladsy herhaal. Vanuit die teoretiese leksikografie se aandrang op verhoogde toegangsmoontlikhede in woordeboeke word die gehalte van die leksikografiepraktyk verhoog - ook deur die gebruik van prentjies as kitstoegangmerkers.

\section{Hibridiese makrostrukturele aanbod}

\subsection{Beginnerwoordeboekgebruik}

Gebruikersbehoeftes en die wisselwerking tussen teorie en praktyk lei ook tot vernuwende benaderings waar 'n tipologiese hibridisering, 'n kenmerk van die hedendaagse leksikografiese praktyk, 'n vermenging van makrostrukturele ordeningsmetodes na vore bring. Daar is reeds 'n tradisie van woordeboeke waarin die sentrale teks, dit is die artikeltrajekte met die verstekleksikografiese bewerking, aangevul word met bylae en ander tekste met bykomende data. Hierdie soort aanbieding is meestal op 'n woordeboekspesifieke en lukrake manier gedoen. Dit is veral danksy die siening in die teoretiese leksikografie dat 'n woordeboek 'n draer van verskillende tekssoorte is dat die bevestiging van die raamstruktuur en 'n uitgebreide benutting 
van buitetekste algemene praktyk geword het. Geïntegreerde en funksionele niegeïntegreerde buitetekste word in sowel die voortekste- as die agtertekste-afdeling van woordeboeke en dikwels ook in 'n middeltekste-afdeling aangebied. Die noodsaak vir meer as net 'n sentrale teks is reeds deur Hausmann en Wiegand (1989:331) beklemtoon toe hulle gesê het dat elke woordeboek minstens twee tekste moet bevat, te wete die sentrale teks en 'n buiteteks, normaalweg in die voortekste-afdeling aangebied, waarin die gebruiksleiding van die spesifieke woordeboek aangebied word.

In die beplanning van die dataverspreidingstruktuur van 'n woordeboek het leksikograwe die geleentheid om oor die aard en omvang van die beplande data-aanbod van die betrokke woordeboek te besluit, maar ook oor die plasing van die data en die teks waar spesifieke data geplaas moet word. Dit is belangrik om daarop te let dat buitetekste data op verskillende maniere kan huisves. Daar kan byvoorbeeld tekste met 'n normale sintaksis of tekste met 'n leksikografiese struktuur en nienatuurlike sintaksis wees. In die laasgenoemde geval waar verskillende tekste byvoorbeeld 'n eie makrostruktuur vertoon, hoef 'n bepaalde woordeboek nie homogene makrostrukture in die verskillende tekste te hê nie. Vir die doel van hierdie bespreking word daar voortaan slegs aandag gegee aan buitetekste wat oor 'n eie makrostruktuur beskik. Vir woordeboeke wat verskillende makrostrukture het, onderskei Wiegand en Gouws (2013:83) tussen makrostruktuurreekse en poli-alfabetiese makrostrukture - twee tipes opeenvolging van makrostrukture. Verder is dit belangrik dat die akademiese vlak van die teikengebruiker of die tipologiese aard van 'n woordeboek nie bepalend is vir die omvang of gehalte van daardie woordeboek se teoretiese onderbou nie. 'n Goeie teoretiese basis is ewe belangrik in die beplanning van 'n algemene woordeboek vir laerskoolleerders as ' $n$ vakwoordeboek vir deskundiges op die gebied van teoretiese fisika. Ter illustrasie van 'n vernuwende benadering in die benutting van 'n opeenvolging van makrostrukture word daar vervolgens aandag gegee aan 'n Suid-Afrikaanse woordeboekreeks vir grondslagfaseleerders. Dit is 'n woordeboekreeks waarin daar reeds vyf woordeboeke verskyn het vir moedertaalsprekers van Afrikaans, Sepedi, Tswana, Xhosa en Zoeloe onderskeidelik. Die vyf woordeboeke het dieselfde struktuur. Slegs die Afrikaanse Grondslagfasewoordeboek (Gouws, Potgieter en Burgess 2010) word vir die huidige bespreking gebruik.

Tipologies beskou, is die Grondslagfasewoordeboek, afgekort as GW, 'n eentalige verklarende woordeboek met ' $n$ tweetalige dimensie. Dit is 'n woordeboek vir moedertaalsprekers in die grondslagjare van hulle skoolopleiding en die woordeboek het 'n teksbegrip- en teksproduksiefunksie. Die tweetalige dimensie word bewerk deur die Engelse vertaalekwivalent wat naas die betekenisparafrase verstrek word.

Die raamstruktuur met geïntegreerde buitetekste maak dit vir gebruikers van hierdie woordeboek gou duidelik dat inligting in 'n woordeboek nie net aan die artikels in die sentrale teks onttrek moet word nie. Dié woordeboek probeer woordeboekgebruiksvaardighede reeds by leerders se eerste kennismaking met 'n woordeboek ontwikkel en vaslê. Vervolgens sal enkele makrostrukturele aspekte van hierdie woordeboek aandag kry.

Die GW is 'n woordeboek met 'n opeenvolging van makrostrukture wat tot verskillende tipes behoort. Die woordeboek se makrostrukture word aangetref in die voortekste-afdeling, die sentrale teks asook die agtertekste-afdeling. Die pedagogiese funksie van hierdie woordeboek en die feit dat die teikengebruikers tydens hulle eerste kennismaking met die woordeboek dikwels nog nie behoorlik kan lees nie, lei tot die insluiting van 'n tematiese afdeling in die voortekste-afdeling. Die temas sluit aan by van die werk wat in die kurrikulum van die 
teikengebruikers gedoen word, byvoorbeeld My liggaam; Klere; My familie; Ons huis; Ons pragtige wêreld; en Diere.

Elke afsonderlike tema word op 'n afsonderlike enkel- of dubbelbladsy aangebied met die tema duidelik gestel. Die tematiese aanbieding is deur beeld en deur woord. Die sentrale deel van 'n bladsy bied telkens 'n volkleurprenteplaat waarop dinge wat tot die tema behoort in kleiner prentjies verskyn. Hierdie deel van die aanbieding hanteer elemente van die tema nie as begrippe nie, maar uitsluitlik as beelde. Dit is 'n ostensiewe aanbieding van elemente wat in die woordeboek opgeneem word. Hierdie ostensiewe aanbieding het 'n invloed op die aard van die inligtingsonttrekking. In 'n semasiologiese alfabetiese woordeboek is die rigting van die inligtingsonttrekking vanaf die woord na die betekenis. In 'n tradisionele onomasiologiese tematiese woordeboek is die inligtingsrigting vanaf die begrip na die betekenis. In die GW vind die inligtingsonttrekking anders plaas. Die sentrale prenteplaat se inhoud is die materiaal wat op die betrokke bladsy leksikografies bewerk word. Dié bewerking is in 'n geïntegreerde sekondêre buiteteks (Gouws en Steyn 2005), van die prenteplaat (vergelyk figuur 4).

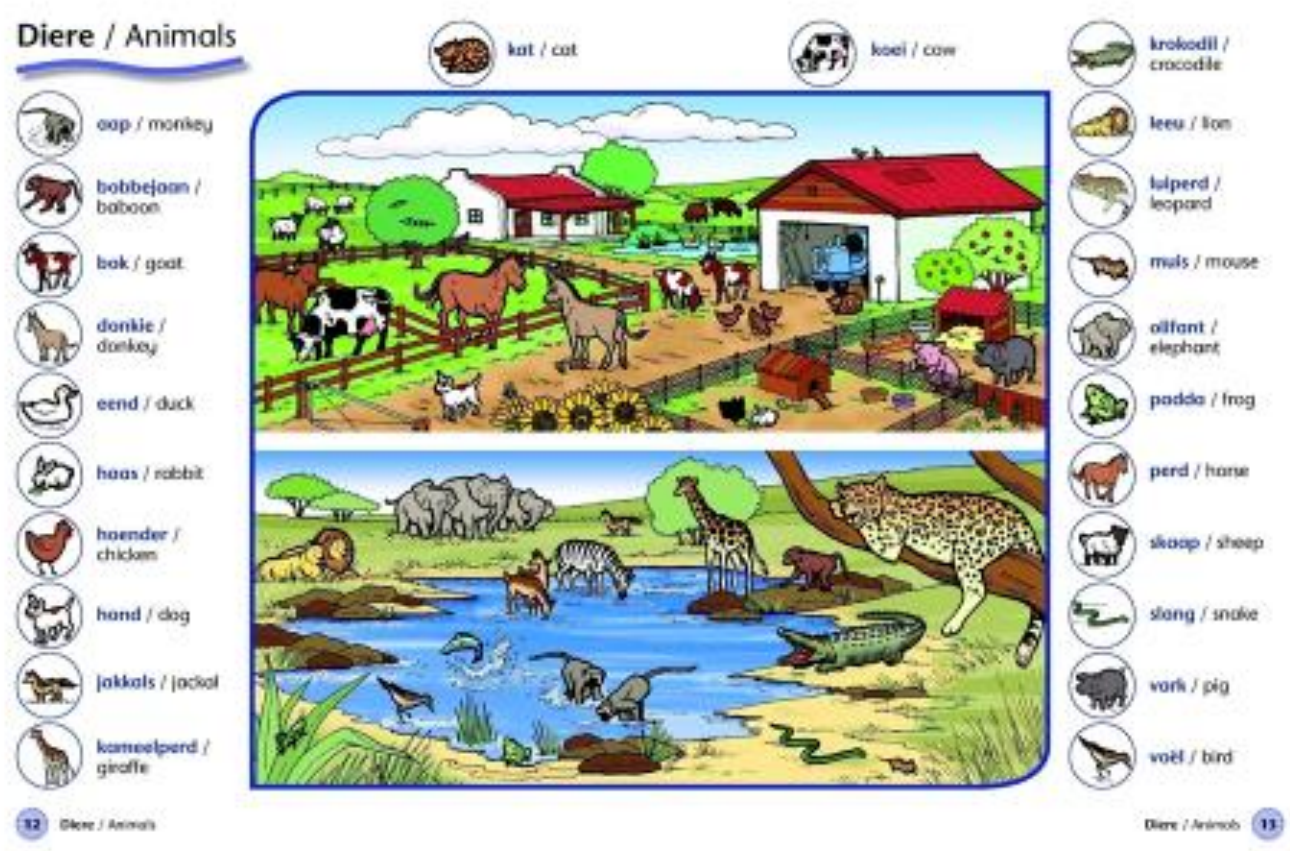

Figuur 4: Diere-prenteplaat in die Grondslagfasewoordeboek (Gouws et al. 2010:12-13)

Die indiwiduele prentjies van die kleurplaat word in die sy- en boonste kolomme georden volgens 'n toegangsalfabet wat met die woordwaarde van die betrokke prentjie werk. Langs elke prentjie is die Afrikaanse woord asook die Engelse ekwivalent. In hierdie makrostruktuur is die prentjies die gidselemente - met werklik sprake van lemmas en nie van trefwoorde nie. Die gebruiker beweeg van die prent in die kleurplaat na die aanbieding van dieselfde prentjie in die makrostruktuur van die sekondêre buiteteks en die inligtingsonttrekking is dan vanaf die prentjie na die woord. 
Alle woorde wat in die tematiese afdelings se opeenvolgende makrostrukture, hier 'n makrostruktuurreeks, as eenwoordverklaring van die prentjies aangebied word, word saam met die prentjie in die sentrale teks verstrek. Alhoewel alfabetiese ordening hier die makrostrukturele plasing bepaal, is dit geen tradisionele makrostruktuur nie. Elke artikel word deur ' $n$ tweekoppige lemma ingelei met twee element-heterogene komponente, te wete 'n prentjie (dieselfde prentjie wat in die tematiese afdeling gebruik word) en die Afrikaanse woord wat daar as verklaring gegee word (vergelyk figuur 5).
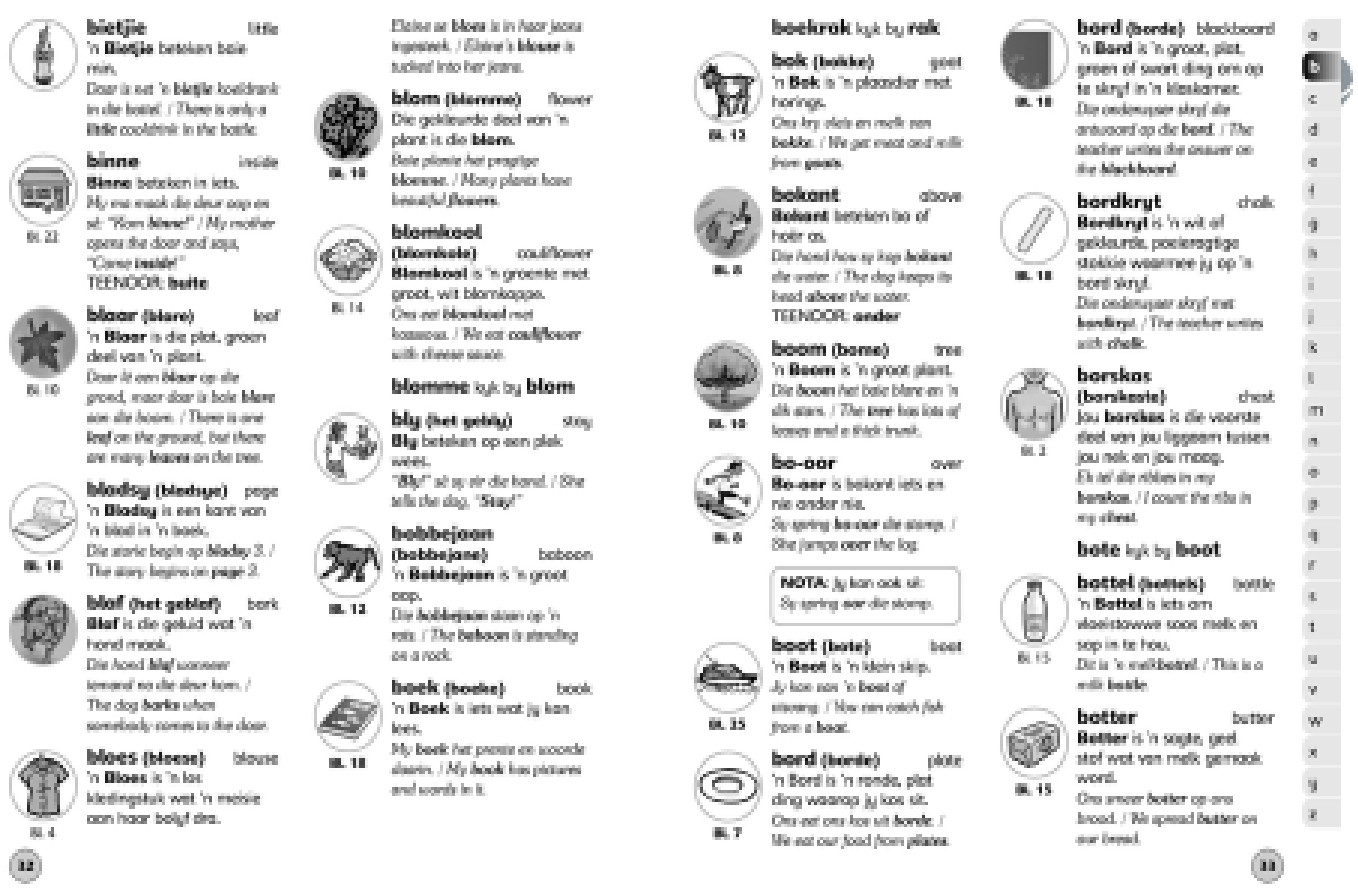

Figuur 5: Deeltrajek uit die Grondslagfasewoordeboek (Gouws et al. 2010:32-33)

Elke deel van dié lemma kan afsonderlik as gidselement van die artikel optree sodat die gebruiker vanaf die prentjie of vanaf die woord na die tersaaklike betekenisparafrase en verdere leksikografiese bewerking gelei word. Die prentjies word in die makrostruktuur gebruik om die gebruiker wat dit in die tematiese deel gesien het, te help met toegang tot die gepaste woordeboekartikel. Die naslaanvaardighede van hierdie woordeboek se teikengebruikers bepaal die hibridiese prentjie-woord-makrostruktuur waarin ordening geskied volgens die alfabetiese waarde van die tweede deel van die tweekoppige lemma met die eerste komponent wat 'n mediostrukturele verband lê met die tersaaklike tematiese teks in die voortekste-afdeling. Tema en alfabet word gebruik in die aanbieding van data in hierdie woordeboek.

\subsection{Gevorderder woordeboekgebruik}

Hibridisering van alfabetiese en tematiese ordening in een woordeboek word dikwels aangetref, vergelyk onder meer die Reader's Digest Afrikaans-Engelse woordeboek/English-Afrikaans 
dictionary (Grobbelaar et al. 1987) met sy alfabeties geordende primêre sentrale teks, ondersteun deur ' $n$ sekondêre makrostruktuur in die sentrale teks en verskillende buitetekste in die agtertekste-afdeling wat 'n afdeling "See and say ... Sien en sê" insluit. Hierdie afdeling bevat ' $n$ makrostruktuurreeks met verskillende temas wat uit prentjies en meegaande byskrifte bestaan. Met behulp van 'n numeriese kruisverwysingstelsel beweeg die gebruiker van die prent na die ondersteunende lys woorde met ekwivalente.

'n Nog innoverender benutting van 'n hibridiese ordening is te vinde in die MED. Hierdie woordeboek se sentrale teks het 'n alfabetiese makrostruktuur. Die raamstruktuur van die MED bevat nie net voor- en agtertekste nie, maar ook ingevoegde binnetekste wat midde-in artikeltrajekte geplaas is. Tussen die trajekte van $\mathrm{M}$ en $\mathrm{N}$ is ' $\mathrm{n}$ ingevoegde teks "Language awareness" wat uit verskillende subtekste bestaan, onder meer Numbers; Phrasal verbs; Academic writing; Computer words; Business English; en andere. Dit is nie tekste wat 'n makrostrukturele aanbod het nie. Daar is wel twee ander ingefaseerde binnetekste, elk in die inhoudsopgawe aangedui as "Colour illustrations". Die eerste is midde-in die artikeltrajek F en die tweede in die artikeltrajek P. Albei hierdie afdelings het 'n tematiese makrostruktuurreeks wat die temas House; Kitchen; Office; Clothes and patterns; Motorway and Types of vehicle; Transport en Car, in die eerste ingefaseerde teks, en Trees, plants and flowers; Fruit; Vegetables; Animals; Sports: football, tennis and golf; Sports: American football, baseball, and basketball en Gym and Games in die tweede ingefaseerde teks per illustrasieprent en byskrifte weergee. Die afsonderlike prentjies wat in elke tematiese teks aangebied word, vertoon oënskynlik geen vaste ordening nie - ook nie volgens die alfabetiese waarde van die saak waarna die prentjie verwys of van die woord wat as byskrif gegee word nie. Volgens Wiegand en Gouws (2013:90) is dit 'n lukraak makrostruktuur, dit wil sê 'n makrostruktuur wat geen ordeningstruktuur in 'n wiskundige sin het nie. Die leksikografieteorie maak voorsiening vir die soort aanbieding wat in die MED gevolg word. Vanuit die sentrale teks is daar kruisverwysings na hierdie ingefaseerde tematiese binnetekste. In die artikel van die lemma jeans is daar byvoorbeeld 'n eksplisiete kruisverwysingsinskrywing "picture $\rightarrow \mathrm{C} 4$ ". C4 is die nommer van die tematiese teks Clothes and patterns. In hierdie tematiese teks het die byskrif jeans die tersaaklike prentjie as adres, maar die lemma jeans in die sentrale teks skakel per afstandsadressering deur middel van 'n kruisverwysingsmerker met die illustrasieprentjie. Tussen die sentrale teks en die ingevoegde teks is daar ' $n$ wisselwerking wat bydra tot die moontlikheid van 'n verhoogde inligtingsonttrekking aan die aangebode data.

\section{Ter afsluiting}

Ook die oorgang vanaf die gedrukte na die aanlyn era skep nuwe ordeningsmoontlikhede wat die tematiese ordening opnuut onder die aandag van leksikograwe bring. Dit is 'n onderwerp wat uitvoerige bespreking verdien, maar nie in hierdie artikel aan die orde gestel word nie.

Uit die geskiedenis van die praktiese leksikografie blyk dit dat daar sekere herhalende werkswyses en prosedures voorkom, onder meer die benutting van tematiese ordening. Hierdie ordeningstipe speel tans 'n ondergeskikte rol aan die alfabetiese ordening. Die wisselwerking tussen teorie en praktyk in die leksikografie en die ruimte wat in die teoretiese leksikografie bepleit word vir diverse benaderings in die strukture, funksies en data-aanbod van woordeboeke lei ook tot 'n nuwe waardering van die tematiese ordening. Die benutting van verskillende ordeningstipes in een woordeboek verhoog dikwels die gebruikersvriendelikheid van daardie woordeboek en bied toegang tot data waaraan 'n groter groep gebruikers op 'n makliker en 
suksesvoller manier die verlangde inligting kan onttrek om geslaagder woordeboeknaslaanprosedures te verseker.

\section{Erkenning}

This work is based on research supported in part by the National Research Foundation of South Africa (Grant specific unique reference number (UID) 85434). The Grantholder acknowledges that opinions, findings and conclusions or recommendations expressed in any publication generated by the NRF supported research are that of the author(s), and that the NRF accepts no liability whatsoever in this regard.

\section{Bronnelys}

Al-Kasimi, A.M. 1977. Linguistics and bilingual dictionaries. Leiden: E.J. Brill.

Bergenholtz, H., S. Tarp en H.E. Wiegand. 1999. Datendistributionsstrukturen, Makro- und Mikrostrukturen in neueren Fachwörterbüchern. In L. Hoffmann et al. (reds.) Fachsprache/Languages for special purposes. An international handbook of special-language and terminology research. Berlyn: De Gruyter. pp. 1762-1832.

Bolinger, D. 1985. Defining the indefinable. In R. Ilson (red.) Dictionaries, lexicography and language learning. Oxford: Pergamon Press. pp. 69-73.

De Stadler, L.G. en A. de Stadler. 1994. Groot tesourus van Afrikaans. Johannesburg: Southern Boekuitgewers.

De Villiers, M., J. Smuts, L.C. Eksteen en R.H. Gouws. 19877. Nasionale woordeboek. Kaapstad: Nasou.

Du Plessis, M. (red.). 2005. Pharos Afrikaans-Engels/English-Afrikaans woordeboek/ dictionary. Kaapstad: Pharos.

Gouws, R., L. Potgieter en S. Burgess (reds.). 2010. Grondslagfasewoordeboek Afrikaans/English. Kaapstad: Maskew Miller Longman.

Gouws, R.H. 1989. Leksikografie. Kaapstad: Academica.

Gouws, R.H. 2004. Outer texts in bilingual dictionaries. Lexikos 14: 67-88.

Gouws, R.H. 2007. Sublemmata or main lemmata: A critical look at the presentation of some macrostructural elements. In H. Gottlieb en J. Mogensen (reds.) Dictionary visions, research and practice. Amsterdam: John Benjamins. pp. 55-69.

Gouws, R.H. 2014. Leksikografie. In W.A.M. Carstens en N. Bosman (reds.) Kontemporêre Afrikaanse taalkunde. Pretoria: Van Schaik. pp. 373-407.

Gouws, R.H. en D. Prinsloo. 2005. Principles and practice of South African lexicography. Stellenbosch: African SunMedia.

Gouws, R.H. en M. Steyn. 2005. Integrated outer texts: a transtextual approach to lexicographic functions. In I. Barz, H. Bergenholtz en J. Korhonen (reds.) Schreiben, Verstehen, Übersetzen und Lernen: Zu ein- und zweisprachigen Wörterbüchern mit Deutsch. Frankfurt: Peter Lang. pp. 127-136. 
Gove, P.B. 1961. Webster's third new international dictionary of the English language. Springfield, MA: Merriam-Webster.

Grobbelaar, P. et al. (reds.). 1987. Reader's Digest Afrikaans-Engelse woordeboek/English-Afrikaans dictionary. Kaapstad: The Reader's Digest Association.

Hausmann, F. J. en H.E. Wiegand. 1989. Component parts and structures of general monolingual dictionaries: A survey. In F.J. Hausmann et al. (reds.) Wörterbücher. Dictionaries. Dictionnaires. An international encyclopedia of lexicography. Berlyn: De Gruyter. pp. 328-360.

Jones, K.L. et al. (reds.). 2014. Jul'hoan Tsumkwe dialect/Prentewoordeboek vir kinders/Children's picture dictionary. Pietermaritzburg: University of KwaZulu-Natal Press.

Kammerer, M. en H.E. Wiegand. 1998. Über die textuelle Rahmenstruktur von Wörterbüchern. Präzisierungen und weiterführende Überlegungen. Lexicographica 14: 224-238.

Louw, J.P. en E.A. Nida. 1988. Greek-English lexicon of the New Testament based on semantic domains. New York: United Bible Societies.

McArthur, T. 1986. Worlds of reference. Cambridge: Cambridge University Press.

Rundell, M. (red.). 2002. Macmillan English dictionary (MED). Oxford: Macmillan Publishers.

Wiegand, H.E. 1989. Aspekte der Makrostruktur im allgemeinen einsprachigen Wörterbuch: alphabetische Anordnungsformen und ihre Probleme. In F.J. Hausmann et al. (reds.) Wörterbü̈cher. Dictionaries. Dictionnaires. An international encyclopedia of lexicography. Berlyn: De Gruyter. pp. 371-409.

Wiegand, H.E. 2002. Über textuele Strukturen der Wörterbuchartikel und Artikelnischen im DE Gruyter Wörterbuch Deutsch Als FremdsPrache. In H.E. Wiegand (red.) Perspektiven der pädagogischen Lexikographie des Deutschen II. Tübingen: Max Niemeyer. pp. 497-595.

Wiegand, H.E. 2009. Nichtnatürlich über natürliche Sprache schreiben. Zu einigen formalen Aspekten von Wörterbuchartikeln. In E. Felder (red.) Heidelberger Jahrbücher 53: 247-285.

Wiegand, H.E. en S. Beer. 2013. Access structures in printed dictionaries. In R.H. Gouws et al. (reds.) Dictionaries. An international encyclopedia of lexicography. Supplementary volume: Recent developments with focus on electronic and computational lexicography. Berlyn: De Gruyter. pp. 110-149.

Wiegand, H.E. en R.H. Gouws. 2013. Macrostructures in printed dictionaries. In R.H. Gouws et al. (reds.) Dictionaries. An international encyclopedia of lexicography. Supplementary volume: Recent developments with focus on electronic and computational lexicography. Berlyn: De Gruyter. pp. 73-110. 